\title{
Chronic exposure to high glucose decreases myo-inositol in cultured cerebral microvascular pericytes but not in endothelium
}

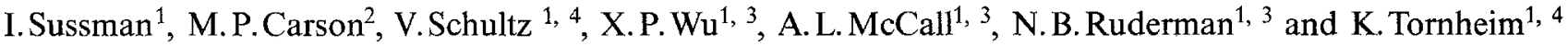 \\ ${ }^{1}$ Division of Diabetes and Metabolism, Evans Memorial Department of Medicine, ${ }^{2}$ Mallory Institute of Pathology, and Departments of \\ ${ }^{3}$ Physiology and ${ }^{4}$ Biochemistry, Boston University School of Medicine, Boston, Massachusetts, USA
}

\begin{abstract}
Summary. It has been proposed that the development of diabetic complications may involve a depletion of cellular myo-inositol due to an increase in polyol (sorbitol) formation. We therefore initially examined the effect of diabetes on levels of these metabolites in isolated cerebral microvessels. Compared with microvessels from control rats, microvessels from diabetic animals showed no detectable alteration in myo-inositol levels and a small increase in sorbitol content. To assess whether myo-inositol depletion might occur in only certain microvascular cells, cultured bovine cerebral microvascular pericytes and endothelium were grown for 3 or $18-20$ days at $1.1,5.5$, or $22.2 \mathrm{mmol} / 1$ glucose, Increased medium glucose concentration resulted in increased sorbitol content in both cell types after both periods of incubation $(p<0.05)$. In contrast, a significant decrease in myo-inositol content $(22 \%, p<0.01)$ was observed only in
\end{abstract}

pericytes grown for 18-20 days in the high glucose medium. Neither the adenosine $5^{\prime}$-triphosphate content nor the adenosine $\quad 5^{\prime}$-triphosphate/adenosine $\quad 5^{\prime}$-diphosphate (ATP/ADP) ratio of the pericytes was affected by the medium glucose concentration, indicating that the decrease in myo-inositol was not caused by a deficiency in the cellular energy state affecting the active transport of myo-inositol. These data suggest that myo-inositol depletion occurs selectively in the pericyte, a cell type known to be the site of early morphological changes in diabetes. Furthermore, the depletion apparently requires prolonged exposure to high glucose and is not due to a change in energy state.

Key words: $M y o$-inositol, sorbitol, microvessels, pericytes, endothelium, ATP, ADP, streptozotocin-diabetes.
An increasing body of evidence has supported the hypothesis, recently reviewed by Winegrad [1], that a common mechanism is involved in the induction of diabetic neuropathy [2], nephropathy [3], retinopathy [4], and embryopathy [5], as well as increased vascular permeability in granulation tissue [6]. According to this hypothesis, hyperglycaemia causes increased flux through aldose reductase and thus, elevated levels of intracellular polyols (e.g. sorbitol). By mechanisms still undetermined, the high glucose and/or polyol levels cause a decrease in tissue myo-inositol [7]. It has been suggested that depletion of a myo-inositol pool decreases the turnover of a small pool of phosphatidylinositol which is involved in the regulation of the $\mathrm{Na}^{+} / \mathrm{K}^{+}$ATPase [8]. The applicability of this sequence of events to cerebral microvascular tissue has not yet been evaluated.

Although the brain has not been considered a primary site of clinical pathology in diabetes, the involvement of the cerebral microvasculature is suggested by observations of basement membrane thickening, altered autoregulation of blood flow [9], increased permeability [10], and pericyte degeneration [11-13]. That metabolic changes do occur in this tissue is indicated by the earlier demonstration in our laboratory of an inhibition of glucose oxidation in cerebral microvessels isolated from diabetic rats $[14,15]$. In the present study, we have examined whether alterations in sorbitol and myo-inositol levels in cerebral microvessels are another consequence of diabetes. In addition, we evaluated the effect of culture in an elevated glucose medium on two microvascular cells types, endothelium and pericytes.

\section{Materials and methods}

\section{Animals and microvessel preparation}

Sprague-Dawley male rats (140-160 g; Charles River Laboratories, Wilmington, Mass, USA) and New Zealand white male rabbits $(2.6-2.8 \mathrm{~kg})$ were used. The rats were made diabetic with streptozotocin $(65 \mathrm{mg} / \mathrm{kg}$; Calbiochem, La Jolla, Calif, USA) either one or eight weeks prior to killing and the rabbits with alloxan $(150 \mathrm{mg} / \mathrm{kg}$; Sigma Chemical Co, St. Louis, Mo, USA) 6 weeks before the study. Diabetes was confirmed by blood glucose levels greater than $14 \mathrm{mmol} / 1$ both $48-72 \mathrm{~h}$ after its induction and 1-4 days prior to killing. The cerebral microvessels were isolated from 13-15 diabetic and aged-matched control rats or rabbits by the method of Brendel [16] as adapted by Sussman et al. [17] with the following modifications: 
the cerebral cortex homogenate was serially sieved through nylon meshes (Small Parts, Inc., Miami, Fl, USA) with pore sizes of 149 , 105 , and 74 (twice) $\mu \mathrm{m}$. The material retained by the 105 and $74 \mu \mathrm{m}$ meshes was sprayed off the meshes using a syringe fitted with a 25-gauge needle containing an Earle's salt solution (in $\mathrm{mmol} / 1$, $118 \mathrm{NaCl}, 5.4 \mathrm{KCl}, 1.8 \mathrm{CaCl}_{2}, 1.0 \mathrm{MgSO}_{4}$ and $\left.1.0 \mathrm{NaH}_{2} \mathrm{PO}_{4}\right)$ with $28 \mathrm{mmol} / \mathrm{l}$ 4-(2-hydroxyethyl)-1-piperazine- $\mathrm{N}^{\prime}$-2-ethanesulfonic acid (HEPES), $\mathrm{pH} 7.4,5.5 \mathrm{mmol} / 1$ glucose and $0.2 \%$ bovine albumin. The resulting microvessels were hand homogenised ( 8 times) in an Ace homogeniser with a Teflon pestle (clearance of $0.1-0.15 \mathrm{~mm}$ ) and exhaustively (10 times) passed through a $37 \mu \mathrm{m}$ mesh. The microvessels retained on the mesh were removed using a stream of medium. After the final microvessel preparation was washed three times in phosphate buffered saline (in mmol/l, $137 \mathrm{NaCl}, 2.7 \mathrm{KCl}, 8 \mathrm{Na}_{2} \mathrm{HPO}_{4}$, $1.5 \mathrm{KH}_{2} \mathrm{PO}_{4}$ ), the metabolites were extracted from the cell pellet by adding $150 \mu \mathrm{l}$ of cold $0.6 \mathrm{~mol} / 1$ trichloroacetic acid. The samples were placed on ice for $10 \mathrm{~min}$ to allow for complete extraction, and the precipitated protein was removed by centrifugation. The trichloroacetic acid was removed by ether extraction. Samples were stored at $-20^{\circ} \mathrm{C}$ until use.

\section{Isolation and culture of cerebral microvascular endothelium and pericytes}

Calf cerebral microvascular endothelium and pericytes were isolated and cultured as described previously [18]. Cells were grown in Corning T25 culture flasks (Corning Glassworks, Corning, NY, USA) and re-fed every other day including the day prior to the experiment. The day after plating the cells were fed with the appropriate medium [18] containing the appropriate glucose concentration; the glucose concentration of $1.1 \mathrm{mmol} / \mathrm{l}$ in this formula was increased as needed by addition of $\alpha-\mathrm{D}[+]$-glucose (Sigma). ( $M y o$-inositol measurements of representative samples of media of the two cell types were found to be in the range of 50-60 $\mu \mathrm{mol} / 1$.) The cells were then grown for 3 or 18-20 days. In the latter case they were continuously passed in the appropriate glucose medium. Three days prior to use the cells were passed for a final time such that at the time of study the microvascular endothelial cells (MEC) were confluent, and the pericytes were in a semi-confluent state. Prior to metabolite extraction the culture medium was removed and the monolayer was rapidly washed 4 times with $5 \mathrm{ml}$ of cold $\left(4^{\circ} \mathrm{C}\right)$ phosphate buffered saline. The cells were then incubated with $1.5 \mathrm{ml}$ of cold $\left(4^{\circ} \mathrm{C}\right) 0.6 \mathrm{~mol} / 1$ trichloroacetic acid for $10 \mathrm{~min}$. The supernatant was removed from the flask and the trichloroacetic acid extracted with ether. Half of the extract was used for analysis of ATP and ADP, either immediately or after being quick-frozen in a dry-ice/ethanol bath and stored overnight at $-20^{\circ} \mathrm{C}$. The remainder of the extract was concentrated approximately 5-fold with a Speed-Vac 100 (Savant, Farmingdale, NY, USA) and was used for determination of myo-inositol and sorbitol.

\section{Assays}

ATP, ADP, and sorbitol were assayed by modified enzymatic methods [19-21] using a Hewlett-Packard (Palo Alto, Calif, USA) model 8450 spectrophotometer system set to read $A_{335-345}$ minus $A_{390-400}$. (The assay for sorbitol is not entirely specific and registers other polyols as well.) $M y o$-inositol was determined using a modification of the enzymatic cycling reaction of MacGregor and Matschinsky [22]. Protein was measured by the method of Lowry et al. [23] after digestion in $0.5 \mathrm{~N} \mathrm{NaOH}$ for $1 \mathrm{~h}$ at $60^{\circ} \mathrm{C}$. Enzymes and biochemicals were obtained from Boehringer Mannheim (Indianapolis, Ind, USA) and Sigma.

\section{Statistical analysis}

The values for the cultured cells are presented as the means \pm SEM of 3-5 experiments. The value used for each experiment is the mean of the metabolite content measured from 3 individual culture flasks.
The experiments were designed such that the cells in the replicate flasks of each individual experiment were from the same isolate. Cells from different isolates were used in different experiments. Statistical significance was determined using a 2-way analysis of variance (ANOVA) for repeated measurements followed by a Duncan's multiple range test; $p<0.05$ was considered to be significant [24]. To compare the ATP/ADP ratios of the two cell types and to analyse the data for the isolated microvessels, a one-way ANOVA followed by a Duncan's multiple range test was performed.

\section{Results}

\section{Isolated microvessels}

The sorbitol level in microvessels isolated from diabetic rats was found to be slightly (1.4-2.3-fold) higher than that of control rats (Table 1). Neither acute (1 week) nor chronic ( 8 weeks) diabetes resulted in a depletion of the myo-inositol content of cerebral microvessels. The myo-inositol content of cerebral microvessels isolated from rabbits was also unaltered by 6 weeks of diabetes $(5.6$ and $5.3 \mathrm{nmol} / \mathrm{mg}$ protein for the control and diabetic groups respectively; $n=2$ ). The lack of a decrease of myo-inositol was seen even when the microvessels from the diabetic rat were isolated in media containing 25 instead of $5.5 \mathrm{mmol} / 1$ glucose (Table 1; Exp. B) and in four additional experiments in which microvessels from diabetic rabbits were isolated in $20 \mathrm{mmol} / 1$ glucose (data not shown).

\section{Cultured pericytes and endothelium}

One possible explanation for the apparent absence of myo-inositol depletion in the isolated microvessels relates to their cellular composition. Previous histologi-

Table 1. Effect of diabetes on the sorbitol and myo-inositol contents of isolated rat cerebral microvessels

\begin{tabular}{|c|c|c|c|c|c|}
\hline \multirow[t]{2}{*}{$\begin{array}{l}\text { Experi- } \\
\text { ment }\end{array}$} & \multirow[t]{2}{*}{$\begin{array}{l}\text { Duration } \\
\text { of diabetes }\end{array}$} & \multicolumn{2}{|c|}{$\begin{array}{l}\text { Sorbitol } \\
\text { (nmol/mg protein) }\end{array}$} & \multicolumn{2}{|c|}{$\begin{array}{l}\text { Myo-inositol } \\
\text { (nmol/mg protein) }\end{array}$} \\
\hline & & Control & Diabetic & Control & Diabetic \\
\hline A & 1 week & ND & ND & 1.49 & 1.52 \\
\hline B & & 0.12 & 0.24 & 1.78 & 1.78 \\
\hline $\mathrm{C}$ & & 0.08 & 0.11 & 1.45 & 1.91 \\
\hline D & & 0.05 & 0.20 & 2.12 & 2.27 \\
\hline$\underset{S E M}{\operatorname{mean}} \pm$ & & $0.08 \pm 0.02$ & $0.18 \pm 0.04$ & $1.71 \pm 0.16$ & $1.90 \pm 0.15$ \\
\hline E & 8 weeks & 0.14 & 0.16 & 1.79 & 1.96 \\
\hline F & & 0.14 & 0.20 & 1.10 & 1.10 \\
\hline $\mathrm{G}$ & & 0.17 & 0.27 & 3.69 & 3.72 \\
\hline $\begin{array}{l}\text { mean } \pm \\
\text { SEM }\end{array}$ & & $0.15 \pm 0.01$ & $0.21 \pm 0.03$ & $2.19 \pm 0.77$ & $2.26 \pm 0.77$ \\
\hline
\end{tabular}

Cerebral microvessels from control and diabetic rats were isolated in parallel. The isolation medium (Earle's-HEPES, pH 7.4) contained $5.5 \mathrm{mmol} / 1$ glucose, except in the case of the diabetic rats of Exp. B where the glucose concentration was $25 \mathrm{mmol} / \mathrm{l}$. ND, not determined 
cal examination of our preparation indicated that the predominant cellular constituent is the endothelium. Approximately $5 \%$ of the microvascular cells are pericytes, with a varying but minor percentage of smooth muscle cells resulting from the presence of some arterioles and venules. Thus, if myo-inositol depletion occurred only in the pericytes, it would be masked by the relatively large contribution of the endothelium. To address this issue we investigated the effect of different medium glucose concentrations on the individual cell types using cultured bovine cerebral microvascular endothelium (MEC) and pericytes.

Growth for 18-20 days in high glucose medium $(22.2 \mathrm{mmol} / \mathrm{l})$ resulted in a 2.5 - to 3.4 -fold rise in sorbitol in both confluent MEC and sub-confluent pericytes; however, myo-inositol depletion occurred only in the pericytes, not in MEC (Fig. 1). The magnitude of decrease in myo-inositol $(22 \%)$ is similar to that reported for other affected tissues [2-5] irrespective of

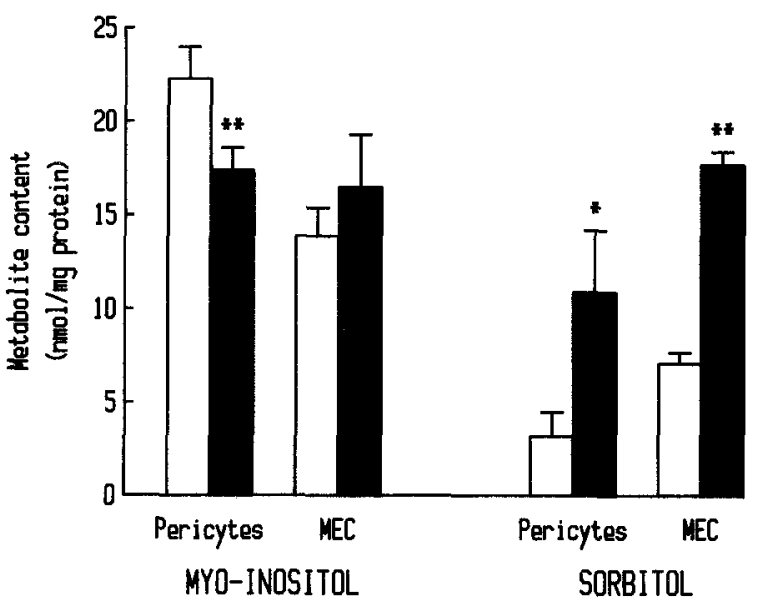

Fig. 1. Myo-inositol and sorbitol contents of cerebral microvascular endothelium (MEC) and pericytes cultured in $5.5 \mathrm{mmol} / 1$ ( $\square$ ) and $22.2 \mathrm{mmol} / 1$ (正 glucose for 18-20 days. The data are calculated from 3 or 4 experiments; the value for each experiment was the mean of 3 culture flasks. * Significantly different from $5.5 \mathrm{mmol} / 1$ glucose control at $p<0.05 ; * *$ Significantly different from $5.5 \mathrm{mmol} / 1$ glucose control at $p<0.01$

Table 2. ATP and ADP contents and ATP/ADP ratios of bovine cerebral microvascular cells cultured at different glucose concentrations for 18-20 days

\begin{tabular}{llll}
\hline $\begin{array}{l}\text { Medium glucose } \\
(\mathrm{mmol} / \mathrm{l})\end{array}$ & \multicolumn{2}{l}{$\begin{array}{l}\text { ATP } \\
\text { (nmol/mg protein) }\end{array}$} & ATP/ADP \\
\hline & & Pericytes \\
1.1 & $23.0 \pm 2.6$ & $2.9 \pm 0.4$ & $8.1 \pm 0.4$ \\
5.5 & $22.7 \pm 2.2$ & $3.1 \pm 0.5$ & $7.8 \pm 0.5$ \\
22.2 & $21.9 \pm 0.4$ & $3.0 \pm 0.2$ & $7.4 \pm 0.3$ \\
& & Endothelium & \\
1.1 & $23.7 \pm 2.3$ & $1.6 \pm 0.2$ & $16.3 \pm 2.2$ \\
5.5 & $22.7 \pm 1.6$ & $1.6 \pm 0.2$ & $15.8 \pm 2.2$ \\
22.2 & $22.0 \pm 2.0$ & $1.5 \pm 0.2$ & $15.2 \pm 1.3$ \\
\hline
\end{tabular}

The data are expressed as the mean \pm SEM, calculated from 3-5 experiments; the value for each experiment was the mean of 3 culture flasks whether it is expressed per mg protein or per nmol ATP. The myo-inositol depletion was observed in each of the three separate experiments (range 19-25\%). In contrast myo-inositol depletion (of more than 4\%) was not seen in any of four similar experiments in which pericytes were exposed for only 3 days to $22.2 \mathrm{mmol} / 1$ glucose, despite a similar rise in sorbitol as for 18-20 day exposure (data not shown). Studies using cells at other stages of growth and/or confluency were not performed.

The effect of growth in a low $(1.1 \mathrm{mmol} / \mathrm{l})$ glucose medium for 18-20 days was also examined. Cell growth, as determined from the final protein content per flask, was not affected by this low glucose concentration in either cell type. Sorbitol content decreased to $1.3 \pm 0.4$ and $1.5 \pm 0.1 \mathrm{nmol} / \mathrm{mg}$ protein for pericytes and MEC, respectively, compared to the values of $3.2 \pm 1.3$ and $7.1 \pm 0.6$ in $5.5 \mathrm{mmol} / 1$ glucose. There was no corresponding rise in myo-inositol content in $\operatorname{MEC}(13.1 \pm 3.0$ vs $13.9 \pm 1.5$ for 1.1 and $5.5 \mathrm{mmol} / 1$ glucose, respectively) and in pericytes, if anything, a small drop $(19.2 \pm 0.7$ vs $22.3 \pm 1.7$ for 1.1 and $5.5 \mathrm{mmol} / 1$ glucose; this drop was not statistically significant by other statistical tests such as ANOVA followed by a Student's $t$-test, $p>0.05$ ).

\section{$A T P$ and $A D P$ contents}

Since cellular myo-inositol accumulation involves an energy-linked transport process, the decreased myoinositol level in pericytes grown in high glucose medium might have been due to perturbation of the energy state of the cell. We therefore measured the ATP content and ATP/ADP ratio. Culture in high $(22.2 \mathrm{mmol} / \mathrm{l})$ or low $(1.1 \mathrm{mmol} / \mathrm{l})$ glucose medium had no effect on these energy parameters (Table 2). The ATP contents of the two cell types were similar; however, the ATP/ADP ratio of the pericytes was significantly less $(p<0.05)$ than that of the MEC.

\section{Discussion}

The experiments presented here show a depletion of myo-inositol in cerebral microvascular pericytes cultured for 18-20 days in a high $(22.2 \mathrm{mmol} / \mathrm{l})$ glucose medium. Such a depletion was not observed in cultured endothelium, although both cell types exhibited a significant increase in sorbitol content. Thus an elevation in sorbitol is not necessarily accompanied by a decrease in myo-inositol levels in all cells. This cell specificity is of particular interest since pericyte degeneration is one of the earliest morphological manifestations of diabetic retinopathy [25]. The basis for the differential effect of high glucose levels on myo-inositol in the two cell types remains to be determined. Hypothetically it could reflect differences in their ability 
to synthesize myo-inositol from glucose [26] or differential impairment of myo-inositol transport. A number of previous studies suggest that polyol accumulation secondary to incubation with high concentrations of glucose or galactose inhibits myo-inositol transport in some cell types and tissues [27, 28] including the pericyte. Where studied this inhibition appears to be reversed by the addition of an aldose reductase inhibitor (e.g. 29).

In the present study sorbitol levels were increased both at 3 and 18-20 days of incubation of the pericytes in a high glucose medium whereas a decrease in myoinositol was noted only at the later time. Studies addressing the reason for this should yield insight into the mechanism(s) responsible for myo-inositol depletion.

No decrease in myo-inositol was detected in cerebral microvessels isolated from diabetic animals. This is consistent with the lack of a decrease in myo-inositol in cultured endothelium, the predominant cell type in the microvessels. The observed $22 \%$ decrease in myoinositol in pericytes, which comprise only about $5 \%$ of the cells in the microvessels, would amount to only a $1 \%$ change in total myo-inositol in the vessel. It should be noted that other metabolic changes in isolated cerebral microvessels $[14,15]$ and functional and metabolic abnormalities in other organs $[2-4,6]$ are observed in rats made diabetic for these time periods.

The tissue contents of sorbitol and myo-inositol in the isolated cerebral microvessels (Table 1 ) are considerably lower than those reported for other tissues $[2-5,8]$ and for the component microvascular cells (Fig. 1), although similar to those of granulation tissue [6]. Thus, it is possible that the former values may not represent the true levels of these metabolites in vivo [17]. This might be in part due to damage to the microvessels incurred during isolation, though the $25 \%$ greater intracellular water space per mg protein of the cultured endothelium vs the microvessels [30] also contributes to the difference. As discussed previously [17], values we have obtained for microvessel ATP content ( $2 \mathrm{nmol} / \mathrm{mg}$ protein) and ATP/ADP ratio (about 2), though higher than values previously obtained by others, are also lower than those for the cultured cells (Table 2). Since myo-inositol accumulation is energylinked, the lower energy state indicated by the ATP/ADP ratio of the microvessels might contribute to the lower myo-inositol content. Alternatively, this relative difference might reflect alterations in the metabolism of recently proliferating, cultured cells vs the microvessels. In this regard, the loss of the marker enzyme alkaline phosphatase within $48 \mathrm{~h}$ of culturing microvascular endothelial cells [18] shows that significant changes in enzyme activities and, hence, metabolite levels are certainly possible.

It has been proposed that diabetic complications occur specifically in tissues sensitive to hyperglycaemia as a result of myo-inositol depletion due to in- creased aldose reductase activity [1]. Our data suggest a further localisation of myo-inositol depletion to specific cell types in an affected tissue. A linkage between $m y o$-inositol depletion and impaired $\mathrm{Na}^{+} / \mathrm{K}^{+}$ AT-Pase activity has been proposed [2-4]. It should be noted, however, that this hypothesis may represent an oversimplification of the state of events in certain tissues and under certain circumstances. Thus, Simmons et al. [8] have reported a decrease in $\mathrm{Na}^{+} / \mathrm{K}^{+}$ATPase activity in aortas incubated with a myo-inositol-free medium and yet found no decrease in tissue myo-inositol. They presented data suggesting that the decrease in $\mathrm{Na}^{+} / \mathrm{K}^{+}$ATPase was due to depletion of a small intracellular myo-inositol pool which did not mix freely with total tissue myo-inositol. Similar inconsistencies between myo-inositol depletion and $\mathrm{Na}^{+} / \mathrm{K}^{+}$ ATPase activity have been observed in other studies $[31,32]$. How myo-inositol depletion relates to $\mathrm{Na}^{+} / \mathrm{K}^{+}$ATPase activity in the pericyte and other vascular cells remains to be determined.

Acknowledgments. This work was supported in part by USPHS grants HL26895, DK31559, DK39814, NS22213, and RR05487-20 and a grant-in-aid (to KT) from the American Diabetes Association. Dr. Sussman was supported by a postdoctoral fellowship from the Juvenile Diabetes Foundation and USPHS grant DK08048. We are grateful to Ms. E. Bercel and Ms. Z. Stitt for their technical assistance and to Dr. G. Berry for measuring the myo-inositol of the media and sera.

\section{References}

1. Winegrad AI (1987) Does a common mechanism induce the diverse complications of diabetes? Diabetes $36: 396-406$

2. Greene DA (1986) A sodium-pump defect in diabetic peripheral nerve corrected by sorbinil administration: relationship to myoinositol metabolism and nerve conduction slowing. Metabolism 35 [Suppl 1]: 60-65

3. Cohen MP (1986) Aldose reductase, glomerular metabolism, and diabetic nephropathy. Metabolism 35 [Suppl 1]: 55-59

4. MacGregor LC, Matschinsky FM (1986) Experimental diabetes mellitus impairs the function of the retinal pigmented epithelium. Metabolism 35 [Suppl 1]: 28-34

5. Sussman I, Matschinsky FM (1988) Diabetes affects sorbitol and myo-inositol levels of neuroectodermal tissue during embryogenesis in the rat. Diabetes 37: 974-981

6. Williamson JR, Chang $\mathrm{K}$, Rowold $\mathrm{E}$, Marvel J, Tomlinson M, Sherman WR, Ackermann KE, Kilo C (1986) Diabetes-induced increase in vascular permeability and changes in granulation tissue levels of sorbitol, myo-inositol, chiro-inositol, and scyloinositol are prevented by sorbinil. Metabolism 35 [Suppl 1]: 41-45

7. MacGregor LC, Stramm LE, Matschinsky FM, Aquirre GD (1987) Glucose or sorbitol causes myo-inositol depletion in cultured RPE cells. Invest Opthal Vis Sci 28 [Suppl]: 382

8. Simmons DA, Kern EFO, Wingrad AI, Martin DB (1986) Basal phosphatidylinositol turnover controls aortic $\mathrm{Na}^{+} / \mathrm{K}^{+}$ATPase activity. J Clin Invest $77: 503-513$

9. Parving HH, Viberti GC, Keen $H$, Christiansen JS, Lassen NA (1983) Hemodynamic factors in the genesis of diabetic microangiopathy. Metabolism 32: 943-949

10. Lorenzi M, Henly DP, Hawkins R, Printa JM, Printz MP (1986) Studies on the permeability of the blood-brain barrier in experimental diabetes. Diabetologia 29: 58-62 
11. Johnson PL, Brendel K, Meezan E (1982) Thickened cerebral cortical capillary basement membranes in diabetics. Arch Pathol Lab Med 106 (5): 214-217

12. Junker U, Jaggi C, Bestetti G, Rossi GL (1985) Basement membrane of hypothalamus and cortex capillaries from normotensive and spontaneously hypertensive rats with streptozotocin-induced diabetes. Acta Neuropathol (Berl) 65: 202-208

13. Mukai N, Hor S, Pomeroy M (1980) Cerebral lesions in rats with streptozotocin-induced diabetes. Acta Neuropathol 51: 79-84

14. McCall AL, Sussman I, Tornheim K, Cordero R, Ruderman NB (1988) Effects of hypoglycemia and diabetes on fuel metabolism by isolated rat cerebral microvessels. Am J Physiol 254: E272-E278

15. McCall AL, Gould JB, Ruderman NB (1984) Diabetes-induced alterations of glucose metabolism in rat cerebral microvessels. Am J Physiol 247: E462-E467

16. Brendel K, Meezan E, Carlson EC (1974) Isolated brain microvessels: a purified, metabolically active preparation from bovine cerebral cortex. Science 526: 537-546

17. Sussman I, Carson MP, McCall AL, Schultz V, Ruderman NB, Tornheim K (1988) Energy state of bovine cerebral microvessels: comparison of isolation methods. Microvasc Res 35: 167-178

18. Carson MP, Haudenschild CC (1986) Microvascular endothelium and pericytes: high yield, low passage cultures. In Vitro Cell Dev Biol 22: 344-354

19. Lamprecht W, Trautschold I (1974) Determination (of ATP) with hexokinase and glucose-6-phosphate dehydrogenase. In: Bergmeyer HU (ed) Methods of enzymatic analysis, Vol 4. Academic Press, New York, pp 2101-2110

20. Jaworek D, Gruber W, Bergmeyer HU (1974) Adenosine-5'-diphosphate and adenosine-5'-monophosphate. In: Bergmeyer HU (ed) Methods of enzymatic analysis, Vol 4. Academic Press, New York, pp 2127-2129

21. Clements RS Jr, Morrison AD, Winegrad AI (1969) Polyol pathway in aorta: regulation by hormones. Science 166: $1007-1008$

22. MacGregor LC, Matschinsky FM (1984) An enzymatic fluorometric assay for myo-inositol. Anal Biochem 141: 382-389

23. Lowry OH, Rosebrough NJ, Farr AL, Randall RJ (1951) Protein measurement with the Folin phenol reagent. J Biol Chem 193: 265-275
24. Armitage $\mathbf{P}$ (1971) Statistical methods in medical research. Wiley, New York

25. Cogan DB, Kinoshita JH, Kador PG, Robison B, Datilis MB, Cobo LM, Kuper C (1985) Aldose reductase and complications of diabetes. Ann Int Med 101: 82-91

26. Wong Y-HH, Kalmback SJ, Harman BK, Sherman WR (1987) Immunohistochemical staining and enzyme activity measurements show myo-inositol-1-phosphate synthase to be localized in the vasculature of brain. J Neurochem 48: 1434-1442

27. Buzney SM, Frank RN, Varma SD, Tanishima T, Gabbay KH (1977) Aldose reductase in retinal mural cells. Invest Opthalmol Vis Sci 16: 292-296

28. Li W, Khatami M, Rockey JH (1985) The effects of glucose and an aldose reductase inhibitor on the sorbitol content and collagen synthesis of bovine retinal capillary pericytes in culture. Exp Eye Res 40: 439-444

29. Li W, Chan LS, Khatami M, Rockey JH (1986) Non-competitive inhibition of myo-inositol transport in cultured bovine retinal capillary pericytes by glucose and reversal by sorbinil. Biochim Biophys Acta 857: 198-208

30. McCall AL, Valente J, Cordero R, Ruderman NB, Tornheim K (1988) Metabolic characterization of isolated cerebral microvessels: ATP and ADP concentrations. Microvasc Res 35: 325-333

31. Lambourne JE, Tomlinson DR, Brown AM, Willars GB (1987) Opposite effects of diabetes and galactosaemia on adenosine triphosphatase activity in rat nervous tissue. Diabetologia 30 : $360-362$

32. Yeh L-A, Rafford CE, Goddu KJ, Ashton MA, Beyer TA, Hudson NJ (1987) $\mathrm{Na}^{+} / \mathrm{K}^{+}$ATPase pumping activity is not directly lined to myo-inositol levels after sorbinil treatment in lenses of diabetic rats. Diabetes 36: 1414-1419

Received: 6 April 1988

and in revised form: 2 August 1988

Dr. I. Sussman

Diabetes \& Metabolism E-211

Boston University School of Medicine

80 E. Concord Street

Boston, MA 02118

USA 